\title{
PENGEMBANGAN DESA WISATA BERBASIS PARTISIPASI MASYARAKAT LOKAL DI DESA WISATA LINGGARJATI KUNINGAN, JAWA BARAT
}

\author{
Oleh: \\ Ade Jafar Sidiq \& Risna Resnawaty \\ (ade_jafarsdiq@yahoo.com; risna.resnawaty@unpad.ac.id)
}

\begin{abstract}
ABSTRAK
Partisipasi masyarakat merupakan prasyarat penting dalam pelaksanaan pembangunan. Pembangunan yang tidak melibatkan masyarakat akan cenderung memarginalkan masyarakat itu sendiri. Namun pada kenyataannya sering terjadi pengabaian partisipasi masyarakat, sehingga masyarakat masih menjadi objek dari pelaksanaan pembangunan.

Pengembangan desa wisata merupakan sebuah perubahan terencana yang di dalamnya membutuhkan partisipasi masyarakat lokal secara holistik. Penelitian ini bertujuan mengkaji keterlibatan masyarakat dalam pengembangan desa wisata dan merumuskan model pengembangan desa wisata yang mengedepankan partisipasi masyarakat lokal. Pengembangan desa Linggarjati Kabupaten Kuningan, Jawa Barat menjadi desa wisata belum melibatkan partisipasi masyarakat. Tantangan dalam proses pengembangan desa wisata di Linggarjati adalah dominasi pemerintah dalam keseluruhan proses. sehingga masyarakat tidak memiliki kesempatan dan kemauan untuk berpartisipasi penuh. Padahal bila mengacu pada pendekatan tata kelola pemerintah yang bersih dan berkelanjutan peran pemerintah diharapkan menjadi fasilitator dengan memberikan peran dan manfaat yang lebih besar kepada masyarakat lokal. Diperlukan kemauan politik pemerintah untuk mengurangi perannya dalam pengembangan desa wisata dengan membuka ruang bagi masyarakat untuk berpartisipasi.
\end{abstract}

\section{Kata Kunci: Pengembangan Masyarakat, Desa Wisata, Partisipasi Masyarakat.}

\section{PENDAHULUAN}

Desa Linggarjati terletak di Kecamatan Cilimus, Kabupaten Kuningan, Jawa Barat. Berjarak sekitar $5 \mathrm{~km}$ dari pusat kota Kabupaten Kuningan, dan sekitar $30 \mathrm{~km}$ dari kota Cirebon Jawa Barat. Desa Linggarjati adalah sebuah desa dataran tinggi yang terletak di kaki Gunung Ciremai. Desa ini berada di ketinggian 500-1500 meter dari permukaan laut dan memiliki curah hujan rata-rata 2500 $\mathrm{mm} /$ tahun. Suhu udara berkisar antara 260290C sehinggga udara di sini tergolong sejuk. Topografi desa ini berbukit-bukit dengan kemiringan mencapai 600 sehingga persawahan sebagai lahan utama penghidupan Penduduk harus dibuat bertingkat-tingkat (berteras). Terasering sawah dibuat selain untuk memenuhi fungsi utamanya sebagai pengatur irigasi persawahan, juga merupakan cermin dari bertahannya kebudayaan lokal, khususnya bertahannya sistem mata pencaharian di bidang pertanian. Kondisi alam Desa Linggarjati yang masih asri, persawahan berteras yang tertata rapi menjadi daya tarik utama desa ini. Selain keindahan terasering sawah, sumber daya alam dan budaya yang 
berpotensi untuk dijadikan atraksi wisata, misalnya, Pemandian air panas, air terjun, gedung bersejarah perjanjian linggarjati, dan wisata kuliner khas Kuningan serta pusat oleholeh khas Kuningan, menambah pesona Desa Linggarjati sebagai daerah wisata.

Keindahan alam Desa Linggarjati dengan taman wisata alam telah diakui sebagai salah satu kekuatan utama kepariwisataan di Kuningan. Taman wisata alam telah memposisikan Linggarjati sebagai salah satu objek yang termasuk dalam situs warisan budaya dunia sehingga berkemampuan untuk menggerakkan minat wisatawan untuk melakukan kunjungan ke Linggarjati. Penetapan Linggarjati sebagai warisan budaya dunia dinilai strategis terutama sebagai upaya mendorong partisipasi masyarakat local dalam pelestarian sumber daya yang berbasis kekuatan nilai-nilai budaya yang ada, mendorong pengembangan wilayah, dan peningkatan kesejahteraan masyarakat lokal. Namun, kenyataan di lapangan menunjukkan bahwa pengembangan Desa Wisata belum berpihak kepada masyarakat Linggarjati. Contohnya, sawah dan petani merupakan aset pariwisata yang dijual untuk kepuasan wisatawan. Namun, pengembangan desa wisata tidak berpihak kepada kehidupan petani. Petani tetap miskin sementara investor meraup keuntungan besar dari aktivitas pariwisata ini. Padahal, jika tidak ada sawah dan petani pariwisata di Linggarjati tidak akan berkembang.

Masuknya kaum kapitalis dalam pengembangan desa wisata membangun area kompetisi ekonomi. Kompetisi tidak saja dalam perebutan lapangan pekerjaan juga dalam hal modal. Kelompok kapitalis lokal bersaing dengan pemodal kuat dari luar Desa bahkan berasal dari luar Kuningan. Jika kondisi ini dibiarkan akan menimbulkan ketidakadilan ekonomi antara masyarakat lokal dengan pendatang. Ketidakadilan berpotensi terjadinya konflik. Oleh karena itu, memberi ruang gerak bagi tumbuhnya ekonomi kerakyatan sangat diperlukan. Jika tidak, kenyamanan desa wisata Linggarjati akan dipertaruhkan. Pariwisata dapat menghancurkan sendi-sendi kehidupan masyarakat desa. Tulisan ini bertujuan untuk mengkaji keterlibatan masyarakat lokal dalam pengembangan desa wisata dan mengkaji model pengembangan desa wisata berbasis partisipasi masyarakat lokal. Kajian ini diharapkan dapat meningkatkan akselerasi pengembangan desa wisata yang mampu merangkul semua pemangku kepentingan agar dapat berperan strategis dalam pengembangan desa wisata. Pihak terkait dapat berpartisipasi dalam peningkatan kompetensi masyarakat lokal untuk pemberdayaan masyarakat lokal.

Pembangunan berbasis masyarakat (community based tourism-CBT) merupakan model pembangunan yang memberikan peluang yang sebesar-besarnya kepada masyarakat pedesaan untuk berpartisipasi dalam pembangunan pariwisata. CBT merupakan sebuah kegiatan pembangunan pariwisata yang dilakukan sepenuhnya oleh masyarakat. Ide kegiatan dan pengelolaan dilakukan seluruhnya oleh masyarakat secara partisipatif, dan manfaatnya dirasakan langsung oleh masyarakat lokal. Dengan demikian, dalam CBT peran masyarakat local sebagai pemangku kepentingan merupakan unsur terpenting dalam pengembangan desa wisata. Desa wisata merupakan salah satu bentuk penerapan pembangunan pariwisata berbasis masyarakat dan berkelanjutan. Melalui pengembangan desa wisata diharapkan terjadi pemerataan yang sesuai dengan konsep pembangunan pariwisata yang berkesinambungan. Di samping itu, keberadaan desa wisata menjadikan produk wisata lebih bernilai budaya pedesaan sehingga pengembangan desa wisata bernilai budaya tanpa merusaknya. Inskeep (1991) mengatakan bahwa Desa Wisata merupakan bentuk pariwisata yang sekelompok kecil wisatawan tinggal di dalam atau di dekat kehidupan tradisional atau di desa-desa terpencil dan mempelajari kehidupan desa dan lingkungan setempat.

Nuryanti (1992) mendefinisikan desa wisata merupakan suatu bentuk integrasi antara atraksi, akomodasi, dan fasilitas pendukung yang disajikan dalam suatu struktur 
kehidupan masyarakat yang menyatu dengan tata cara dan tradisi yang berlaku. Ditegaskan pula bahwa komponen terpenting dalam desa wisata, adalah (1) akomodasi, yakni sebagian dari tempat tinggal penduduk setempat dan atau/ unit-unit yang berkembang sesuai dengan tempat tinggal penduduk, dan (2) atraksi, yakni seluruh kehidupan keseharian penduduk setempat beserta latar fisik lokasi desa yang memungkinkan berintegrasinya wisatawan sebagai partisipan aktif, seperti kursus tari, bahasa, lukis, dan hal-hal lain yang spesifik.

Kaitannya dengan konsep pengembangan desa wisata, Pearce (1995) mengartikan pengembangan desa wisata sebagai suatu proses yang menekankan cara untuk mengembangkan atau memajukan desa wisata. Secara lebih spesifik, pengembangan desa wisata diartikan sebagai usaha-usaha untuk melengkapi dan meningkatkan fasilitas wisata untuk memenuhi kebutuhan wisatawan. Masyarakat lokal berperan penting dalam pengembangan desa wisata karena sumber daya dan keunikan tradisi dan budaya yang melekat pada komunitas tersebut merupakan unsur penggerak utama kegiatan desa wisata. Di lain pihak, komunitas lokal yang tumbuh dan hidup berdampingan dengan suatu objek wisata menjadi bagian dari sistem ekologi yang saling kait mengait. Keberhasilan pengembangan desa wisata tergantung pada tingkat penerimaan dan dukungan masyarakat lokal. Masyarakat local berperan sebagai tuan rumah dan menjadi pelaku penting dalam pengembangan desa wisata dalam keseluruhan tahapan mulai tahap perencanaan, pengawasan, dan implementasi.

\section{Partisipasi Masyarakat Linggarjati dalam Proses Pengembangan Desa Wisata}

Partisipasi masyarakat dalam pembangunan merupakan hal yang penting ketika diletakkan atas dasar keyakinan bahwa masyarakatlah yang paling tahu apa yang dibutuhkan. Partisipasi yang hakiki akan melibatkan masyarakat dalam keseluruhan tahapan pengembangan, mulai dari proses perencanaan, pengambilan keputusan, dan pengawasan program pengembangan desa wisata. Keikutsertaan masyarakat ini sangat dipengaruhi oleh kemauan, kesempatan, dan kemampuan dari masyarakat tersebut Keikutsertaan masyarakat dalam perencanaan desa wisata dapat mendorong mereka berpartisipasi aktif dalam pelaksanaan dan pengawasan. Berdasarkan hal tersebut dapat dirumuskan model pengembangan pariwisata berbasis masyarakat. Berikut ini akan dijelaskan partisipasi masyarakat dalam keseluruhan tahap pengembangan sebagai berikut.

\section{Partisipasi Masyarakat dalam Tahap Perencanaan}

Parameter yang digunakan untuk menentukan derajat partisipasi masyarakat dalam tahap perencanaan adalah keterlibatan dalam identifikasi masalah, perumusan tujuan, dan pengambilan keputusan terkait pengembangan desa wisata. Sebagian besar masyarakat Linggarjati mengaku tidak dilibatkan dalam identifikasi masalah dan tidak ikut terlibat dalam pengambilan keputusan terkait pengembangan desa wisata. Mereka tidak pernah diajak berdialog dalam mengidentifikasi kebutuhan masyarakat lokal. Hal ini terjadi, karena (1) gagasan pengembangan desa wisata dilakukan oleh Pemerintah Kabupaten Kuningan tanpa melibatkan masyarakat sebagai pemilik sumber daya, sehingga masyarakat Linggarjati kurang memahami latar belakang pengembangan desa wisata; (2) masyarakat lokal hanya menjalankan apa yang diprogamkan oleh pemerintah, misalnya, kesediaan menerima kedatangan wisatawan dan menyerahkan lahan untuk dibangun fasilitas wisata; dan (3) masyarakat lokal tidak berkekuatan untuk berpartisipasi aktif dalam arti ikut memberi warna terhadap keputusan yang akan diambil oleh penguasa.

Meskipun masyarakat diundang dalam beberapa rapat perencanaan, partisipasi yang dilakukan oleh masyarakat pada tahap ini tergolong semu. Benefit yang diperoleh dari bentuk partisipasi yang dilakukan tidak menunjukkan hasil yang signifikan, bahkan umpan balik yang disampaikan oleh 
masyarakat lokal atas keputusan yang diambil oleh penguasa sering diabaikan. Padahal substansi dalam pengembangan desa wisata berbasis masyarakat, partisipasi yang dilakukan oleh masyarakat Linggarjati seharusnya bersifat aktif dan langsung. Namun, selalu dihadang oleh keputusan penguasa yang bersifat topdown. Mekanisme seperti ini menjadikan masyarakat Linggarjati tidak terbiasa berpartisipasi. Ketergantungan terhadap pemerintah dan investor tinggi. Kondisi ini berakibat pada kurangnya respons, antusiasme, dan keterlibatan masyarakat dalam pengelolaan dan pengembangan aset-aset di wilayah mereka. Dalam hal keaktifan masyarakat Desa Linggarjati, hasil penelitian menemukan bahwa kehadiran warga dalam pertemuan desa cukup antusias. Walaupun warga masyarakat banyak yang hadir dalam setiap pertemuan, pada umumnya mereka mengaku tidak terlibat dalam pengambilan keputusan perihal pengembangan desa wisata.

Berdasarkan hal tersebut difahami bahwa kesempatan untuk berpartisipasi bagi masyarakat belum terbuka lebar. Masyarakat memiliki kemauan yang besar untuk turut berkontribusi dalam pembangunan wilayahnya, namun kesempatan untuk mengemukakan pendapat dan mengambil keputusan tidak tersedia. Hal ini disebabkan pemerintah telah memiliki rencana pembangunan yang telah dicanangkan sejak tahun-tahun sebelumnya, sehingga masyarakat hanya sebagai objek dari perubahan yang ada.

Isu menarik lainnya adalah keterwakilan masyarakat. Meskipun peserta yang hadir dalam perencanaan pengembangan desa wisata berasal dari berbagai latar belakang, hal ini belum mencerminkan keterwakilan. Pertemuan-pertemuan itu biasanya dihadiri oleh tokoh masyarakat, pejabat desa, kelompok tertentu, warga masyarakat yang berpendidikan, misalnya guru, pegawai negeri sipil, dan rohaniawan, yang secara resmi diundang oleh kepala desa. Kondisi ini mengindikasikan bahwa pengembangan desa wisata belum sepenuhnya melibatkan seluruh lapisan masyarakat hingga level grassroot karena dominasinya adalah golongan menengah ke atas, termasuk para pelajar, orang berpendidikan, dan para pemimpin informal. Sehingga masyarakat yang benar-benar ada di level bawah tidak terdengar aspirasinya.

\section{Partisipasi Masyarakat Lokal dalam Tahap Implementasi}

Parameter Partisipasi masyarakat dalam tahap implementasi adalah keterlibatan di dalam pengelolaan usaha-usaha pariwisata, misalnya, sebagai pengelola penginapan, pengelola rumah makan, pemandu wisata, karyawan hotel, dan pengelola atraksi wisata. Keterlibatan masyarakat lokal dalam tahap implementasi dalam arti pemanfaatan peluang terlihat minim. Sekalipun wujud partisipasi itu ada, bentuknya lebih pada pengelolaan usaha berskala kecil. Hal ini terlihat kontras dengan partisipasi masyarakat luar (investor) yang memonopoli usaha berskala besar. Misalnya, dari tujuh fasilitas wisata berupa 4 buah sarana akomodasi dan 3 buah restoran, lima di antaranya dikelola oleh orang asing, dan hanya dua buah yang dikelola oleh masyarakat lokal. Penyebabnya adalah karena peluang usaha tersebut memerlukan modal besar, risiko bisnis yang tinggi, persaingan ketat, dan menuntut kompetensi yang tinggi.

Masyarakat Linggarjati dengan kompetensi bisnis yang rendah dan keterbatasan modal menyebabkan mereka tidak mampu bersaing dengan para pemilik modal besar yang umumnya berasal dari luar desa. Ironisnya, para pemilik modal besar tidak hanya menekuni usaha berskala besar, juga mengambil alih usaha berskala kecil yang pada mulanya dikelola masyarakat lokal. Akibatnya, sebagian besar hasil usaha tersebut tidak terdistribusi di tingkat lokal melainkan mengalir keluar desa.

Intervensi modal asing yang merambah sampai wilayah pedesaan, menyebabkan terjadinya proses marginalisasi posisi sosial ekonomi masyarakat Linggarjati. Pengembangan desa wisata dipandang sebagai neokapitalis yang hanya mengeksploitasi masyarakat lokal, sementara keuntungan dan manfaat pengembangan desa wisata sebagian 
besar dinikmati kaum kapitalis. Kesenjangan pendapatan dan kesejahteraan antar lapisan masyarakat semakin besar, pada akhirnya, masyarakat lokal tetap berada di posisi marginal dalam usaha yang justru terjadi di wilayahnya sendiri. Kondisi ini mengindikasikan bahwa pengembangan desa wisata belum bermanfaat ekonomis bagi masyarakat Linggarjati. Hal ini didukung dengan masyarakat yang belummemiliki kemampuan untuk terlibat dalam isdustri pariwisata. Menyikapi hal ini idealnya pemerintah harus meningkatkan kapasitas masyarakat lokal agar mampu meraih dampak positif dari perubahan yang terjadi di sekitar mereka.

\section{Partisipasi Masyarakat Lokal dalam Tahap Pengawasan}

Masyarakat lokal memiliki peran kontrol yang sangat substansial dalam pengembangan desa wisata karena control terhadap proses pengambilan keputusan harus diberikan kepada mereka yang nantinya menanggung akibat pelaksanaan pengembangan termasuk kegagalan atau dampak negatip yang terjadi akibat pengembangan desa wisata. Oleh karena itu, kewenangan pengambilan keputusan harus diberikan kepada masyarakat lokal. Parameter partisipasi masyarakat dalam pengawasan adalah keterlibatan dalam tim pengawasan berikut kewenangan yang dimiliki.

Keterlibatan masyarakat local dalam melakukan pengawasan terhadap pengembangan desa wisata terlihat minim. Alasannya, karena perencanaan pengembangan dilakukan oleh pemeritah tanpa melibatkan masyraakat, sehingga masyarakat tidak berkompetensi untuk melakukan pengawasan, dan merasat tidak perlu untuk melakukan pengawasan terhadap apa yang terjadi di sekitar mereka. Pola pembangunan yang top-down tidak melatih masyarakat untuk dapat mengetahui permasalahan dan potensi yang mereka miliki, sehingga mereka gagap dalam menentukan tujuan hidupnya.
Di samping itu pengawasan oleh masyarakat dimaknai oleh pemerintah sebagai tindakan memata-matai program yang dilakukan pemerintah sehingga berujung terjadinya konflik. Pada akhirnya, masyarakat memilih berpartisipasi pada pengawasan yang bersifat preventif untuk mencegah tindakan negatif yang dapat menggangu keamanan desa, misalnya, mengawasi kehidupan anak muda yang mabuk-mabukan di sekitar area kafe Linggarjati di malam hari, pengawasan terhadap pedagang liar yang berjualan di sekitar taman wisata, dan pengawasan parkir kendaraan yang tidak teratur dan sering menimbulkan kemacetan. Sedangkan pengawasan yang bersifat lebih kompleks seperti pelanggaran tata ruang, pelanggaran kawasan asri, sebagian besar warga bersikap tidak peduli, padahal secara substansi seharusnya masyarakat lokal ikut mengawasi. Selama ini pengawasan yang bersifat kompleks hanya dilakukan oleh segelintir masyarakat yang kritis termasuk elite masyarakat lokal.

\section{Model Pengembangan Desa Wisata Berbasis Masyarakat}

Partisipasi masyarakat dalam pengembangan desa wisata pada prinsipnya adalah partisipasi dalam mengelola sumber daya. Oleh karena itu, perlu dirumuskan model yang relevan dalam pelaksanaan program tersebut. Model dipandang sebagai acuan dalam merencanakan, mengimplementasi, dan mengevaluasi program. Sebagai sebuah pendekatan, model yang dirumuskan harus merepresentasikan partisipasi masyarakat dalam setiap aspeknya. Harapan masyarakat Linggarjati dalam pengembangan desa wisata kedepan adalah (1) pengembangan desa wisata harus berpedoman pada potensi masyarakat dan lingkungan; (2) masyarakat harus terlibat penuh dalam pengembangan desa wisata; (3) menghargai hak-hak masyarakat local; (4) memperhatikan kelestarian lingkungan yang ada di sekitar Desa Linggarjati; (5) pemanfaatan rumah penduduk untuk akomodasi wisatawan; dan (6) ada kelembagaan otonom dan mandiri yang 
dibentuk oleh masyarakat lokal dibawah tanggung jawab desa adat. Ada jaminan bahwa masyarakat harus terlibat di dalamnya agar program pengembangan desa wisata berjalan sesuai dengan kebutuhan masyarakat.

Untuk menjamin hal itu dirumuskan hal-hal sebagai berikut. (1) pengembangan desa wisata harus berpedomanan pada kebudayaan local masyarakat; (2) masyarakat lokal menjadi sentral dan menjadikan subjek dari semua proses pengembangan desa wisata. Dengan menempatkan masyarakat sebagai sentral diharapkan partisipasi masyarakat sebagai pemilik sumber daya pariwisata akan terdorong dan mampu menyejahterakan masyarakat local; (3) pengembangan desa wisata membutuhkan adanya kemitraan yang solid antara tiga unsur utama, yaitu pemerintah, swasta, dan lembaga, yang masyarakat lokal menjadi pemangku kepentingan dari kerja sama tersebut; (4) ketiga pemangku kepentingan tersebut berada pada posisi yang sejajar dalam melakukan kerja sama serta saling menghormati; (5) perlu dibentuk badan pengelola yang otonom dan mandiri, yang saling berinteraksi, memberikan umpan balik pelaksanaan untuk mengoreksi diri pada setiap jenjang organisasi; (6) keputusan dan inisiatif untuk memenuhi kebutuhan masyarakat lokal dibuat ditingkat lokal oleh warga masyarakat yang memiliki identitas yang diakui peranannya sebagai partisipan dalam proses pengambilan keputusan; dan (7) fokus utama pengembangan desa wisata adalah memperkuat kemampuan masyarakat lokal dalam mengarahkan dan mengatasi aset-aset yang ada pada masyarakat local untuk memenuhi kebutuhannya.

Pelaksanaan hubungan antar pemangku kepentingan tersebut terarah, peran dan tanggung jawab masing-masing harus jelas. Peran dan kewenangan masing-masing pemangku kepentingan sebagai berikut. Peran dan Kewenangan Pemerintah, yaitu (1) melakukan pembinaan kualitas produk dan kemasan kerajinan dan kuliner khas desa sebagai unsur kenangan wisata; (2) melakukan penataan dan konservasi lingkungan fisik kawasan yang menjadi ciri khas desa wisata;
(3) melakukan perbaikan/pengadaan infrastruktur persampahan dan sanitasi; (4) melakukan gerakan masyarakat untuk mewujudkan sapta pesona; (5) melakukan pembuatan informasi dan fasilitas kepariwisataan; (6) melakukan perbaikan/peningkatan kualitas ruang publik, pedestrian dan landscape desa/lingkungan untuk mendukung sapta pesona; dan (7) dukungan pemberdayaan terhadap kelompok sadar wisata (Pokdarwis) dalam pelestarian lingkungan pariwisata (kawasan Hutan, dan sawah).

Peran dan Kewenangan Swasta (Investor, Perguruan Tinggi, LSM, pelaku pariwisata lainnya), yaitu (1) melakukan promosi terintegrasi antar pengelola objek wisata untuk menggerakkan kunjungan wisatawan antar objek wisata; (2) pembuatan dan pemasaran paket-paket wisata yang kompetitif yang terjangkau masyarakat; (3) pelatihan kewirausahaan, pelatihan keterampilan individual terkait usaha di bidang pariwisata (pelatihan bahasa Inggris, pelatihan hospitality, pelatihan mengenal budaya, dan karakteristik wisatawan dalam dan luar negeri); (4) pengembangan kelompok usaha bersama masyarakat; dan (5) menjalankan bisnis perhotelan, restoran, suvenir, dan lainlain.

Peran masyarakat Lokal, yaitu (1) menyediakan sebagian besar atraksi sekaligus menentukan kualitas produk wisata. Pengelolaan lahan pertanian secara tradisional, upacara adat, kerajinan tangan dan kebersihan merupakan beberapa contoh peran yang memberikan daya tarik bagi pariwisata; (2) pelaku budaya, misalnya, kesenian yang menjadi salah satu daya tarik wisata; dan (3) penyedia akomodasi dan jasa pemandu wisata, penyediaan tenaga kerja, produk makanan khas, kerajinan lokal, kesenian lokal, dan sebagainya.

Peran dan Kewenangan Badan Pengelola, yaitu (1) badan pengelola sebagai pengelola utama dan pengarah dalam perlindungan, perawatan, pelestarian guna mempertahankan fungsinya sebagai desa wisata (cultural and natural heritage); (2) 
melakukan pengaturan yang diperlukan dalam rangka pengembangan Desa Wisata Linggarjati; (3) menyediakan dan mengoperasikan segala fasilitas untuk menunjang kegiatan usaha; (4) memberikan dan mecabut izin penempatan, menetapkan persyaratan-persyaratan, dan menetapkan serta melakukan pungutan segala usaha komersial di Desa Wisata Linggarjati; (5) menetapkan dan memungut biaya/retribusi dan pungutan lainnya atas pemanfaatan fasilitas yang tersedia dan hasil seluruhnya merupakan pendapatan badan pengelola; (6) melakukan perencanaan dalam bidang pengembangan atraksi/produk wisata, pengembangan fasilitas wisata; (8) melakukan pengorganisasian dalam bidang penguatan dan pengembangan kelembagaan; (9) melakukan pengarahan untuk peningkatan kompetensi pengelola objek wisata agar sesuai dengan tujuan pengembangan desa wisata yang berkelanjutan; dan (10) melakukan evaluasi dan pengawasan terhadap aktivitas kepariwisataan agar tercapainya tujuan pengembangan desa wisata yang berkelanjutan.

\section{PENUTUP}

Peran pemerintah dalam pengelolaan sumber daya pariwisata terlihat dominan. Padahal bila mengacu pada pendekatan tata kelola pemerintah yang bersih dan berkelanjutan peran pemerintah diharapkan menjadi fasilitator dengan memberikan peran dan manfaat yang lebih besar kepada masyarakat. Hal ini menunjukkan bahwa pembangunan pariwisata berbasis partisipasi masyarakat belum terwujud di wilayah ini. Masyarakat belum menjadi subjek utama pembangunan, namun masih menjadi objek pembangunan. Hal ini disebabkan kesempatan untuk berpartisipasi masih terbatas. Keran untuk berpartisipasi masih belum terbuka lebar. Masyarakat merasa tergusur oleh perubahan yang terjadi tanpa memiliki kemampuan untuk turut terlibat dalam pembangunan.

Masyarakat lokal khususnya masyarakat Desa Linggarjati perlu diajak untuk mendesain sendiri model pariwisata yang akan dikembangkan. Selama ini pariwisata yang dikembangkan di desa wisata tersebut tidak pernah di desain oleh mereka. Pariwisata yang dikembangkan didesain oleh orang luar desa. Masyarakat lokal terpinggirkan. Pengembangan desa wisata berjalan sesuai dengan kebutuhan masyarakat, harus ada jaminan masyarakat untuk terlibat di dalamnya. Untuk menjamin hal itu diperlukan kemauan politik pemerintah untuk mengurangi peranannya dalam pengembangan desa wisata dan memberikan peranan yang lebih besar kepada masyarakat dengan membuka ruang bagi masyarakat untuk berpartisipasi. Selama ini masyarakat terbiasa menjalankan apa yang diperintahkan oleh pemerintah dan tidak dibiasakan berpartisipasi.

\section{DAFTAR PUSTAKA}

Adi, Isbandi Rukminto. 2001. Pemberdayaan, Pengembangan Masyarakat dan, Intervensi Komunitas. Jakarta: Lembaga Penerbit FE UI.

Widoyoko, Eko Putra. 2009. Evaluasi Program Pembelajaran. Yogyakarta: Pustaka Pelajar.

Hasibuan, Malayu. 2011. Manajemen dasar, pengertian dan masalah. Jakarta: Bumi Aksara.

Fahrudin, Adi. 2012. Pengantar Kesejahteraan Sosial. Bandung: PT. Refika Aditama.

Huraerah, Abu. 2011. Pengorganisasian \& Pengembangan Masyarakat. Bandung: Humaniora.

McDavid, James C. 2006. Program Evaluation \& Performance Measurement. New York: SAGE Publication.

Rothman, Jack. 1995. Strategies Of Community Intervention. F. E. Peacock Publisher.

Suyanto, Bagong. 2013. Anatomi Kemiskinan. Malang: in-TRANS Publishing.

Zubaedi. 2013. Pengembangan Masyarakat: Wacana \& Praktik. Jakarta: Kencana Prenada Media Group. 